Sharif University of Technology
Scientia Iranica
Transactions E: Industrial Engineering
http://scientiairanica.sharif.edu
IRAN I CA

\section{A novel assessment approach to EFQM driven institutionalization using integrated fuzzy multi-criteria decision-making methods}

\author{
Ö. Uygun ${ }^{\mathrm{a}}$, S. Yalçın ${ }^{\mathrm{b}}$, A. Kiraz ${ }^{\mathrm{a}, *}$, and E. Furkan Erkan ${ }^{\mathrm{a}}$ \\ a. Department of Industrial Engineering, Faculty of Engineering, Sakarya University, Turkey. \\ b. Department of Industrial Engineering, Faculty of Engineering and Architecture, Beykent University, Turkey.
}

Received 23 October 2017; received in revised form 19 July 2018; accepted 13 October 2018

KEYWORDS
Computational
organization
performance;
EFQM;
Excellence models;
Fuzzy DEMATEL;
Fuzzy ANP;
VIKOR.

\section{KEYWORDS}

Computational

EFQM;

Excellence models;

Fuzzy ANP;

VIKOR. (2)

\begin{abstract}
It is becoming increasingly difficult for enterprises to survive under competitive conditions. Enterprises with high levels of institutionalization are able to survive and reap more advantages than their competitors. Excellence models are widespread tools for measuring the degree of institutionalization of enterprises. In this study, European Foundation for Quality Management (EFQM) criteria are evaluated with fuzzy multicriteria decision-making techniques. The fuzzy DEMATEL method is used to determine the interactions amongst the main EFQM criteria. According to the relationship diagram obtained from the Fuzzy DEMATEL method, the weights of the subcriteria are calculated according to the expert evaluations using fuzzy analytic network process method. The criterion "Business Results" has been determined to be the most important criterion. The weights of the criteria are taken as input for the VIKOR method. Then, the institutionalization levels of six institutions, previously evaluated by EFQM, are reevaluated by the proposed approach. As a result, institutions A, B, E, and F achieve Excellence Award, while institutions C and D are assessed to deserve the 4-star competency certificate. The institutional scores obtained by the proposed method and the scores given by the EFQM evaluators are statistically analyzed to demonstrate that the proposed method has produced meaningful results.
\end{abstract}

(C) 2020 Sharif University of Technology. All rights reserved.

\section{Introduction}

In today's competitive environment, enterprises must develop new planning and control mechanisms in order to survive, realize their goals, and use their limited resources in the most efficient ways. Enterprises seek new ways to evaluate their business performance and

*. Corresponding author. Tel.: +902642953717 E-mail addresses: ouygun@sakarya.edu.tr (Ö. Uygun); selinyalcin@beykent.edu.tr (S. Yalçın); kiraz@sakarya.edu.tr (A. Kiraz); eneserkan@sakarya.edu.tr (E. Furkan Erkan)

doi: $10.24200 /$ sci. 2018.5398 .1259 improve their strategic goals [1]. Enterprises can achieve success in a shorter amount of time when they more accurately and effectively assess performance results in terms of resources and energy. Enterprises should attempt to achieve sustainable growth and reach excellence [2]. They will succeed in excellence when they effectively evaluate their performance results.

Excellence allows companies to survive or thrive based on customer orientation, leadership, sustainable goals, processes, continuous improvement, mutually beneficial partnerships, and social responsibility concepts [3]. Many enterprises prefer excellence models to measure their excellence levels. The main aim of the models is to provide business excellence. The European 
Table 1. Illustration of related literature on EFQM.

\begin{tabular}{|c|c|c|c|c|}
\hline Ref. & Method + EFQM & Aim of the study & Application Area & Year \\
\hline [6] & Fuzzy AHP & Determining a new score of each indicator & Hotel industry & 2017 \\
\hline$[7]$ & Fuzzy DEMATEL & $\begin{array}{c}\text { Assessing causal relationships of } \\
\text { EFQM model criteria }\end{array}$ & Tovseeh Taavon Bank & 2016 \\
\hline$[8]$ & Fuzzy AHP & $\begin{array}{l}\text { Identifying and ranking the factors } \\
\text { affecting organizational agility }\end{array}$ & $\begin{array}{l}\text { Isfahan University of } \\
\text { Medical Sciences }\end{array}$ & 2016 \\
\hline [9] & $\begin{array}{c}\text { Fuzzy ANP + fuzzy TOPSIS } \\
\text { + fuzzy ELECTRE }\end{array}$ & Improving projects of the EFQM & Calcimine company & 2016 \\
\hline$[10]$ & Fuzzy expert system & A new performance assessment system & $\begin{array}{c}\text { Yazd Regional Electricity } \\
\text { Co. in Iran }\end{array}$ & 2016 \\
\hline$[11]$ & $\begin{array}{l}\text { Fuzzy logic }+ \text { AHP } \\
+ \text { operations research }\end{array}$ & $\begin{array}{l}\text { Determining improvement } \\
\text { projects with high priority }\end{array}$ & $\begin{array}{c}\text { Yazd Regional Electricity } \\
\text { Co. in Iran }\end{array}$ & 2015 \\
\hline$[12]$ & TOPSIS & Assessing the organization's performance & An organization & 2013 \\
\hline$[13]$ & AHP & $\begin{array}{l}\text { Evaluating the business } \\
\text { performance excellence }\end{array}$ & $\begin{array}{l}\text { Firms in different } \\
\text { sectors in Turkey }\end{array}$ & 2012 \\
\hline$[14]$ & Fuzzy logic & A new assessment system & $\begin{array}{l}\text { A mega car } \\
\text { manufacturing firm }\end{array}$ & 2011 \\
\hline$[15]$ & Fuzzy MCDM & Best selection of areas for improvement & $\begin{array}{l}\text { A mega car } \\
\text { manufacturing firm }\end{array}$ & 2011 \\
\hline$[16]$ & Fuzzy logic & A new assessment system & - & 2011 \\
\hline
\end{tabular}

Foundation for Quality Management (EFQM) is used by approximately $70 \%$ of European enterprises to conduct self-assessments [4]. It measures the excellence levels of enterprises, identifies their strengths and weaknesses, and helps them to develop solutions to problems [5]. In older versions of EFQM, criteria weights were revised according to current conditions. Although these weights are determined using expert opinions, an analytical approach is not used when taking interactions among the criteria into account. In the proposed method, criteria weights are obtained by taking the effects of criteria on each other into consideration and using the group decision-making approach by acquiring the opinion of many experts. The aim of this study is to propose an approach that enables criteria weights to be obtained analytically by introducing a different perspective on the EFQM excellence model.
Selected studies for examining EFQM, fuzzy logic, and multi-criteria decision-making methods are briefly described in Table 1.

The rest of the paper is organized as follows. Section 2 briefly describes institutionalization as a concept. Section 3 contains the technical background and implementation of the study. In Section 4, the validation of the proposed approach is expressed, while conclusions are provided in Section 5.

\section{Institutionalization}

The creation of an institutional culture via a consistent management philosophy in the long term plays an important role in institutionalization. An organizational structure should be innovative and sensitive to changes by placing importance on vision, mission, and 
long-term strategic planning. Systemic continuity is necessary for the future of institutionalization [17]. Factors affecting institutionalization in general include effective leadership, highly trained employees, a strong information system, and the establishment of an organizational structure and culture [18]. The selfassessment process, crucial to businesses' ability to sustain their assets, enables enterprises to measure the level of institutionalization and evaluate and improve their corporate performance. Most studies in the literature focus on concepts that affect the level of institutionalization. Few studies have been conducted regarding the measurement of the level of institutionalization of enterprises [19]. Accordingly, Uygun et al. [20] proposed institutionalization criteria for Smalland Medium-sized Enterprises (SMEs) and evaluated the readiness assessment of several SMEs using MultiCriteria Decision-Making (MCDM) methods. Today, there are several well-known excellence models used to measure institutionalization levels of enterprises. These models include the Deming Prize, Malcolm Baldrige Model, Canada Awards, Singapore Quality Award, and so on. In addition to these models, the EFQM model was developed by the European Foundation for Quality Management in 1991.

\subsection{Excellence models}

In today's competitive environment, enterprises require assessments from an objective perspective to improve their processes and level of institutionalization. There are three popular business excellence models used for determining the institutionalization level of organizations. The Deming model (since 1951), Baldrige criteria for performance excellence model (since 1987), and European Foundation for Quality Management Excellence Model (since 1991) evaluate organizations based on business excellence criteria to determine their institutionalization tendencies. Each criterion in an excellence model provides a standardized structure in which the performance of an organization can be measured. Such standardization allows for benchmarking and identification of the best performance. Enterprises entitled to receive one of these awards are highly valued in terms of prestige. The criteria and weights of Deming model include policy (10\%), organization (10\%), information (10\%), standardization (10\%), human resources $(10 \%)$, quality assurance $(10 \%)$, maintenance $(10 \%)$, improvement $(10 \%)$, effects $(10 \%)$, and future plans $(10 \%)$. The criteria weights of the Baldrige Model are leadership (10\%), information and analysis $(5 \%)$, strategic planning $(10 \%)$, human resource focus (17\%), process management $(17 \%)$, business results and company performance (24\%), and customer focus and satisfaction (17\%). The EFQM excellence model has five input criteria and four output criteria, which are given in the next section.
The similarities and differences of three models are briefly described in Table 2 .

\subsection{EFQM excellence model}

The EFQM excellence model was created in 1991 by the European Foundation for Quality Management (EFQM) as a tool for self-assessment. This model facilitates an objective and detailed organizational analysis for reaching the intended outcomes from the perspective of total quality management. It maintains a balance by associating different aspects of the organization. The EFQM excellence model not only deals with the issue of quality, but also provides important tools for establishing an effective management system that permeates each stage of management. EFQM is a large organization that brings together more than 400 members from different geographies of the world. The EFQM excellence model consists of 9 main criteria and 32 subcriteria. The main criteria and their weights are "leadership (C1-10\%), strategy (C2-10\%), people (C3-10\%), partnerships and resources (C4-10\%), and processes, products and services (C5-10\%)" whose criteria constitute the "enablers", while "customer (C6$15 \%$ ), people (C7-10\%), society (C8-10\%), and business results (C9-15\%)" constitute the "Results" criteria [5]. The input criteria or enablers are concerned with how the organization performs its activities while the output criteria deal with organizational accomplishments.

The recognition levels of the organizations are determined according to their scores as 3-star $(300+$ points), 4-star (400+ points), and 5 -star $(500+$ points $)$. Organizations, receiving scores of 600 and over, have the "prize(s) winner" based on 8 fundamental concepts (adding value for customers, creating a sustainable future, developing organizational capability, harnessing creativity \& innovation, leading with vision, inspiration \& integrity, managing with agility, succeeding through the talent of people, and sustaining outstanding results). The best organization(s) in realizing these 8 fundamental concepts is entitled to be "award winner".

\section{Methods and implementation}

An integrated fuzzy DEMATEL, fuzzy ANP, and VIKOR methods are used in the proposed approach. The details and equations of the methods are not given here due to text restrictions, but related references are provided for readers who are interested in more details about the methods.

The DEMATEL method provides meaningful structural relationships between parameters in the solution of complex problems. The method is frequently used in solutions such as strategic analysis [22], performance evaluation [23], selection of alternatives [24], etc. Fuzzy DEMATEL method is developed for gathering group ideas and analyzing the cause and effect 
Table 2. Similarities and differences of the excellence models [21].

\begin{tabular}{|c|c|c|c|}
\hline Criteria & Deming model & Baldrige model & EFQM model \\
\hline Leadership & $\begin{array}{l}\text { Less influential than } \\
\text { the other models }\end{array}$ & $\begin{array}{l}\text { Explained by the concepts } \\
\text { of organizational leadership and } \\
\text { community responsibility }\end{array}$ & $\begin{array}{l}\text { More influential than } \\
\text { the other models }\end{array}$ \\
\hline $\begin{array}{l}\text { Strategic } \\
\text { planning }\end{array}$ & $\begin{array}{l}\text { Strategic approaches stated } \\
\text { in policy criterion }\end{array}$ & $\begin{array}{c}\text { Creation and dissemination } \\
\text { of strategies }\end{array}$ & $\begin{array}{c}\text { Creation and dissemination } \\
\text { of strategies }\end{array}$ \\
\hline $\begin{array}{l}\text { Assessment } \\
\text { and } \\
\text { evaluation }\end{array}$ & $\begin{array}{l}\text { Including the improvement and } \\
\text { effects criteria of the model }\end{array}$ & $\begin{array}{l}\text { One of the main criteria in the model. } \\
\text { Measurement and analysis with } \\
\text { an important place }\end{array}$ & $\begin{array}{l}\text { Input and output criteria } \\
\text { focus on performance results }\end{array}$ \\
\hline $\begin{array}{l}\text { Human } \\
\text { resource } \\
\text { management }\end{array}$ & $\begin{array}{l}\text { Human resources criterion includes } \\
\text { the use of statistical methods and } \\
\text { the development of human resources }\end{array}$ & $\begin{array}{l}\text { Human resources focus criterion } \\
\text { including performance evaluation, } \\
\text { recruitment, career development } \\
\text { and working environment }\end{array}$ & $\begin{array}{c}\text { Human resources planning, } \\
\text { identification of } \\
\text { competencies, and authorization } \\
\text { concepts are included } \\
\text { different from other models }\end{array}$ \\
\hline $\begin{array}{l}\text { Process } \\
\text { oriented }\end{array}$ & $\begin{array}{c}\text { Stated as process analysis, control and } \\
\text { improvement concepts in quality } \\
\text { assurance criterion }\end{array}$ & $\begin{array}{l}\text { Stated in process management } \\
\text { criterion and its importance } \\
\text { clearly emphasized }\end{array}$ & $\begin{array}{l}\text { One of the main criteria } \\
\text { (5th) of the model and } \\
\text { its importance is clearly } \\
\text { emphasized }\end{array}$ \\
\hline $\begin{array}{l}\text { Continuous } \\
\text { improvement }\end{array}$ & $\begin{array}{l}\text { Having an important place in the } \\
\text { model since improvement criterion is } \\
\text { among the main criteria }\end{array}$ & $\begin{array}{l}\text { Backed up by major } \\
\text { improvements made } \\
\text { every two years }\end{array}$ & $\begin{array}{l}\text { Carried out by analyzing } \\
\text { the self-assessment report } \\
\text { provided by EFQM assessors } \\
\text { and their feedbacks }\end{array}$ \\
\hline $\begin{array}{l}\text { Social } \\
\text { responsibility }\end{array}$ & $\begin{array}{l}\text { Stated in effect criteria about } \\
\text { relations with companies } \\
\text { and societies }\end{array}$ & $\begin{array}{l}\text { Included in criteria of business } \\
\text { results and social } \\
\text { responsibilities subcriteria }\end{array}$ & $\begin{array}{l}\text { One of the main criteria } \\
(8 \mathrm{th}) \text { of the model }\end{array}$ \\
\hline $\begin{array}{l}\text { Focusing } \\
\text { on output } \\
\text { performance }\end{array}$ & $\begin{array}{l}\text { Including impacts and } \\
\text { future plans criteria }\end{array}$ & $\begin{array}{l}\text { Stated in strategic planning } \\
\text { criterion and its importance is } \\
\text { clearly emphasized }\end{array}$ & $\begin{array}{l}\text { Its importance indicated } \\
\text { in strategy criterion }\end{array}$ \\
\hline $\begin{array}{l}\text { Geographical } \\
\text { region }\end{array}$ & Japan, world-wide & North America & Europe \\
\hline
\end{tabular}

relationship of complex problems in fuzzy environments by Lin and $\mathrm{Wu}[25,26]$. Their developed model is preferred for implementation in this study while obtaining interrelationships among the main EFQM criteria. The fuzzy ANP method will be based on these interrelationships. ANP is based on Analytic Hierarchy Process (AHP) and was developed by Saaty [27] to deal with the problems where interrelationships among the criteria were taken into consideration. There are many fuzzy AHP methods, developed in the literature, available for obtaining the supermatrix in the ANP method. Due to having relatively easier steps than the other developed methods, Chang's extent analysis method [28] is utilized in this study. The weight of each EFQM subcriterion is found analytically by fuzzy ANP method. More details on how to apply fuzzy ANP based on Chang's fuzzy AHP could be found in [20].

In the next step, the scores given to the enterprises by the experts in terms of 32 EFQM subcriteria and the weights of the criteria obtained from the fuzzy 
ANP have been transferred to the VIKOR method. With this method, the institutionalization level of each organization is evaluated and, then, the organizations are ranked. VIKOR method was developed by Opricovic [29] that focused on the selection of the most appropriate alternative by ranking the alternatives among conflicting criteria. The details and the steps of VIKOR method are explained in [30].

The proposed approach and implementation steps are given in Figure 1. During the implementation of the integrated methods, linguistic expressions were transformed into triangular fuzzy numbers by consulting experts who are trained in EFQM, have participated in EFQM applications in their own enterprises, and also have the EFQM evaluator certificate.

In the first step, the effects of the main criteria on each other are evaluated using linguistic expressions by three experts. The experts assess criteria using five linguistic variables \{No influence (No), Very Low influence (VL), Low influence (L), High influence (H), and Very High influence (VH) $\}$.

Linguistic expressions of each expert are transformed into triangular fuzzy numbers as in Table 3. Then, the arithmetic mean values of the triangular fuzzy numbers are calculated to obtain the direct relation fuzzy matrix.

After that, the normalized direct relation fuzzy matrix is calculated and presented in Table 4. The

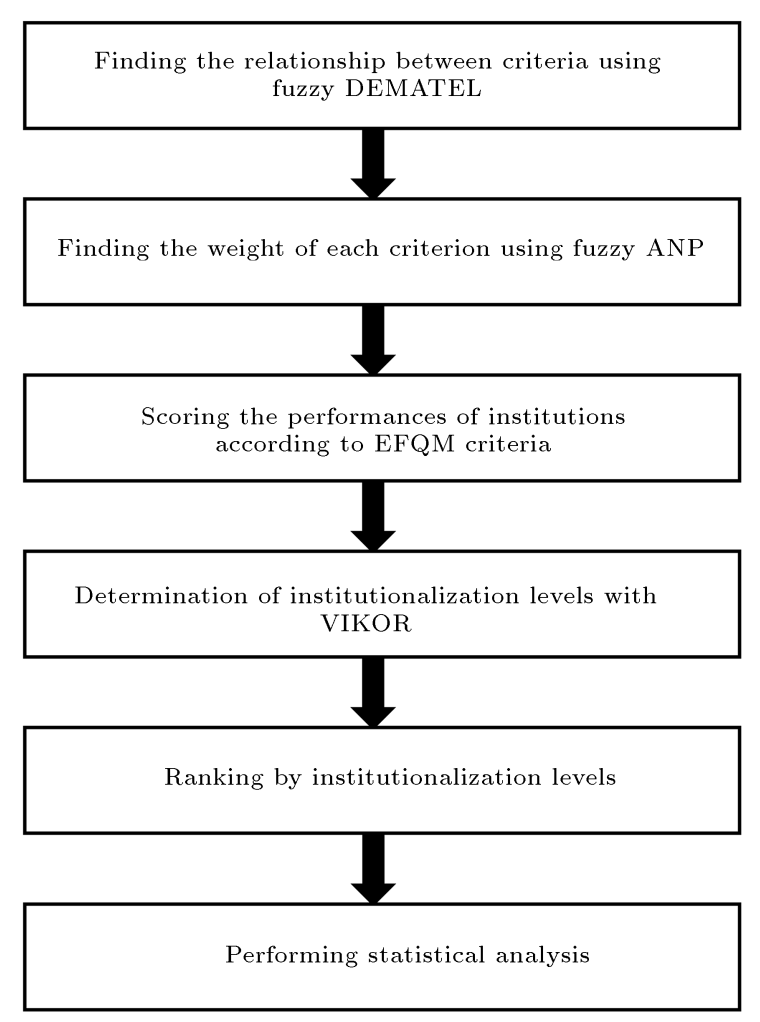

Figure 1. Steps of the proposed approach and implementation. normalized direct relation fuzzy matrix is transformed into the total relation fuzzy matrix, as shown in Table 5. Then, the fuzzy numbers are defuzzified using center of gravity method, as shown in Table 6 , which gives the defuzzified total relation matrix. The threshold value was set to 0.3585 to determine the relationship between the criteria. The values above the threshold value are represented in bold in Table 6, describing the cause-and-effect relationship between the criteria.

According to the interrelationships obtained from the fuzzy DEMATEL method, pairwise comparisons are made to calculate the weights of the sub-criteria of the EFQM excellence model using the fuzzy ANP method. Experts assess sub-criteria according to their importance by using fuzzy linguistic expressions. For example, since the strategy $(\mathrm{C} 2)$ criterion affects the criterion of collaborations and resources $(\mathrm{C} 4)$, the subcriteria of $\mathrm{C} 4$ are evaluated with regard to each subcriterion of $\mathrm{C} 2$. Experts use five linguistic variables Equally Important (EI), Moderately Important (MI), Important (I), Very Important (VI), and Absolutely Important (AI) for the evaluation. Linguistic variables and the corresponding fuzzy numbers for one of the experts are shown in Table 7 , while the geometric averages from all experts, as well as calculated local weights according to ANP procedure, are presented in Table 8.

Similarly, the rest of the interrelationships obtained from fuzzy DEMATEL method are evaluated by the fuzzy ANP process in order to derive all the local weights, which are then put into the unweighted supermatrix. Table 9 gives the unweighted supermatrix in which the local weights given in Table 8 are presented in bold. Then, the weighted supermatrix is calculated by normalizing the unweighted supermatrix. After obtaining the weighted supermatrix, the limit supermatrix is calculated by taking the power of the weighted supermatrix until the values of each column are identical. As seen in Table 10, any column of the limit supermatrix shows the weights of the corresponding subcriteria.

The criteria weights are obtained by calculating the sum of the related subcriteria weights given in Table 10. As a result, the weights of the nine main criteria of the EFQM model are 5, 15, 10, 7, 15, 9, 10, 7 , and $22 \%$, respectively.

The weight of the business results (C9) criterion is much higher than those of the other criteria according to the results of the fuzzy ANP method. The leadership (C1) criterion has the least weight in percentage in the model, because experts consider that business results include leadership criteria while evaluating business results. On the other hand, the literature shows that leadership criteria can comprise other criteria [31].

The VIKOR method has been applied using 


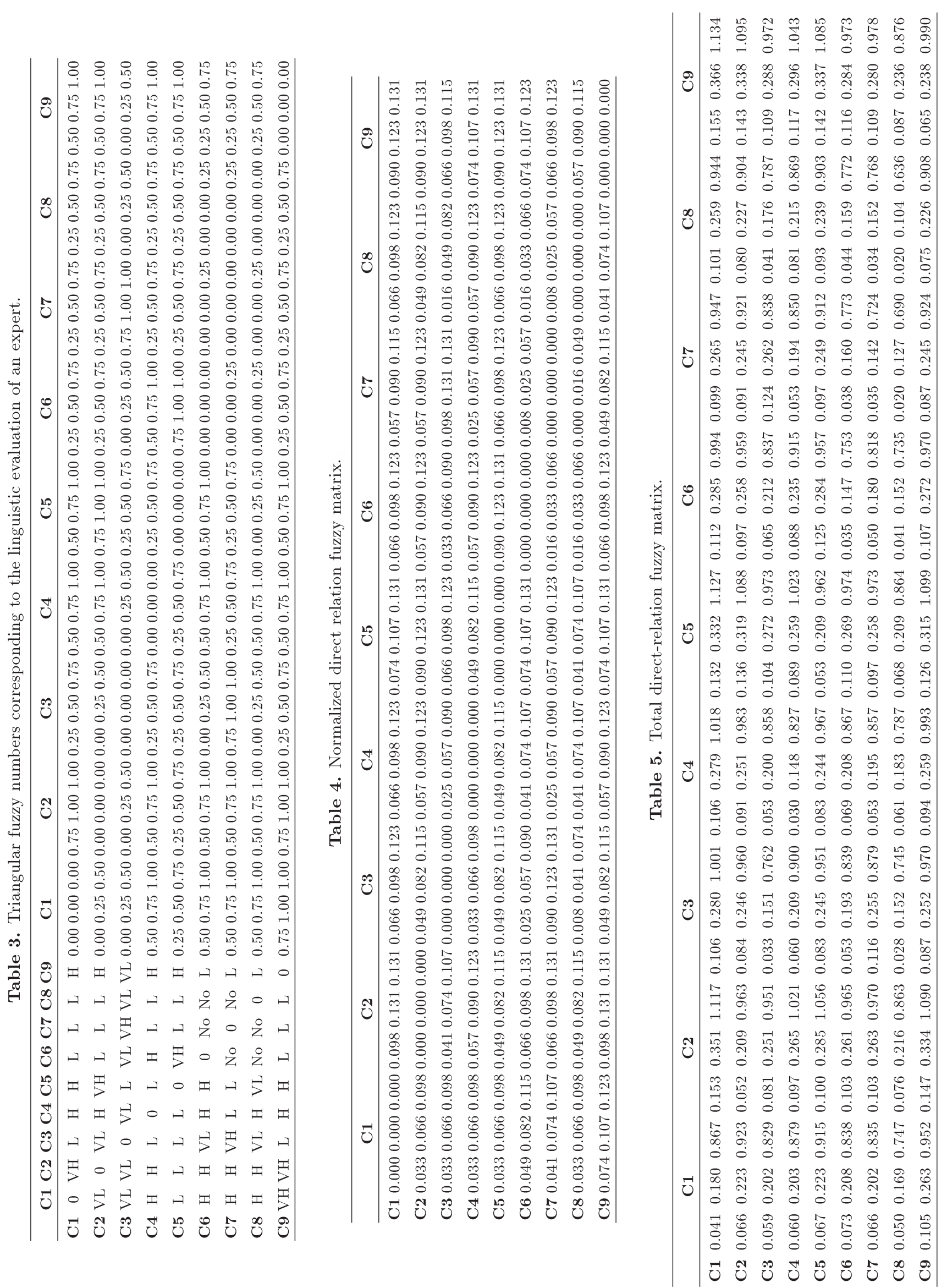


Table 6. Defuzzified total relation matrix.

\begin{tabular}{cccccccccc}
\hline & C1 & C2 & C3 & C4 & C5 & C6 & C7 & C8 & C9 \\
\hline C1 & 0.3170 & $\mathbf{0 . 4 9 3 3}$ & $\mathbf{0 . 4 1 6 7}$ & $\mathbf{0 . 4 2 0 7}$ & $\mathbf{0 . 4 8 0 8}$ & $\mathbf{0 . 4 1 9 0}$ & $\mathbf{0 . 3 9 3 8}$ & $\mathbf{0 . 3 9 1 0}$ & $\mathbf{0 . 5 0 5 5}$ \\
C2 & $\mathbf{0 . 3 5 8 8}$ & 0.3581 & $\mathbf{0 . 3 8 3 8}$ & $\mathbf{0 . 3 9 4 1}$ & $\mathbf{0 . 4 6 5 8}$ & $\mathbf{0 . 3 9 2 9}$ & $\mathbf{0 . 3 7 5 5}$ & $\mathbf{0 . 3 5 9 4}$ & $\mathbf{0 . 4 7 8 7}$ \\
C3 & 0.3230 & $\mathbf{0 . 3 8 3 4}$ & 0.2743 & 0.3277 & $\mathbf{0 . 4 0 5 0}$ & 0.3314 & $\mathbf{0 . 3 7 1 3}$ & 0.2953 & $\mathbf{0 . 4 1 4 1}$ \\
C4 & 0.3359 & $\mathbf{0 . 4 1 2 2}$ & 0.3444 & 0.2884 & $\mathbf{0 . 4 0 7 6}$ & $\mathbf{0 . 3 6 8 5}$ & 0.3228 & 0.3453 & $\mathbf{0 . 4 3 7 9}$ \\
C5 & 0.3570 & $\mathbf{0 . 4 3 1 3}$ & $\mathbf{0 . 3 8 1 0}$ & $\mathbf{0 . 3 8 4 6}$ & 0.3583 & $\mathbf{0 . 4 1 2 2}$ & $\mathbf{0 . 3 7 6 9}$ & $\mathbf{0 . 3 6 8 2}$ & $\mathbf{0 . 4 7 5 6}$ \\
C6 & 0.3315 & $\mathbf{0 . 3 9 7 5}$ & 0.3192 & 0.3382 & $\mathbf{0 . 4 0 5 5}$ & 0.2704 & 0.2828 & 0.2835 & $\mathbf{0 . 4 1 4 3}$ \\
C7 & 0.3265 & $\mathbf{0 . 3 9 9 8}$ & $\mathbf{0 . 3 7 6 3}$ & 0.3249 & $\mathbf{0 . 3 9 6 4}$ & 0.3069 & 0.2606 & 0.2764 & $\mathbf{0 . 4 1 1 8}$ \\
C8 & 0.2839 & 0.3426 & 0.2695 & 0.3034 & 0.3372 & 0.2700 & 0.2410 & 0.2161 & $\mathbf{0 . 3 5 8 6}$ \\
C9 & $\mathbf{0 . 3 9 5 8}$ & $\mathbf{0 . 4 7 6 1}$ & $\mathbf{0 . 3 9 0 4}$ & $\mathbf{0 . 4 0 1 1}$ & $\mathbf{0 . 4 6 3 7}$ & $\mathbf{0 . 4 0 5 1}$ & $\mathbf{0 . 3 7 4 9}$ & $\mathbf{0 . 3 5 8 8}$ & $\mathbf{0 . 3 8 2 7}$ \\
\hline
\end{tabular}

Table 7. Pairwise comparison matrix showing that an expert evaluates sub-criteria of C4 according to C2a.

\begin{tabular}{|c|c|c|c|c|c|c|c|c|c|c|c|c|c|c|c|c|c|c|c|c|c|}
\hline & \multicolumn{6}{|c|}{ Linguistic variables } & \multicolumn{15}{|c|}{ Corresponding fuzzy numbers } \\
\hline \multirow[b]{2}{*}{$4 \mathbf{a}$} & \multirow{2}{*}{$\frac{\mathbf{4 a}}{\mathrm{EI}}$} & \multirow{2}{*}{$\frac{4 \mathbf{b}}{\mathrm{VI}}$} & \multirow{2}{*}{$\frac{4 \mathbf{c}}{\mathrm{VI}}$} & \multirow{2}{*}{$\frac{\mathbf{4 d}}{\mathrm{I}}$} & \multirow{2}{*}{$\frac{4 \mathbf{e}}{\mathrm{VI}}$} & \multirow[b]{2}{*}{$4 \mathbf{a}$} & \multicolumn{3}{|c|}{$4 a$} & \multicolumn{3}{|c|}{$4 b$} & \multicolumn{3}{|c|}{$4 \mathrm{c}$} & \multicolumn{3}{|c|}{$4 d$} & \multicolumn{3}{|c|}{$4 e$} \\
\hline & & & & & & & 1 & 1 & 1 & 5 & 7 & 9 & 5 & 7 & 9 & 3 & 5 & 7 & 5 & 7 & 9 \\
\hline $4 b$ & & EI & MI & EI & & $4 b$ & $1 / 9$ & $1 / 7$ & $1 / 5$ & 1 & 1 & 1 & 1 & 3 & 5 & 1 & 1 & 1 & $1 / 5$ & $1 / 3$ & 1 \\
\hline $4 \mathrm{c}$ & & & EI & & & $4 c$ & $1 / 9$ & $1 / 7$ & $1 / 5$ & $1 / 5$ & $1 / 3$ & 1 & 1 & 1 & 1 & $1 / 5$ & $1 / 3$ & 1 & $1 / 5$ & $1 / 3$ & 1 \\
\hline $4 d$ & & & MI & EI & & $4 d$ & $1 / 7$ & $1 / 5$ & $1 / 3$ & 1 & 1 & 1 & 1 & 3 & 5 & 1 & 1 & 1 & $1 / 5$ & $1 / 3$ & 1 \\
\hline $4 e$ & & MI & MI & MI & EI & $4 e$ & $1 / 9$ & $1 / 7$ & $1 / 5$ & 1 & 3 & 5 & 1 & 3 & 5 & 1 & 3 & 5 & 1 & 1 & 1 \\
\hline
\end{tabular}

Table 8. Geometric averages and calculated weights of sub-criteria of C4 according to C2a.

\begin{tabular}{|c|c|c|c|c|c|c|c|c|c|c|c|c|c|c|c|c|}
\hline & & $4 a$ & & & $4 b$ & & & $4 c$ & & & $4 d$ & & & $4 e$ & & $\mathbf{W i}$ \\
\hline $4 a$ & 1.00 & 1.00 & 1.00 & 1.00 & 1.53 & 3.00 & 3.87 & 5.92 & 7.94 & 3.00 & 5.00 & 7.00 & 1.00 & 1.53 & 3.00 & 0.38 \\
\hline $4 b$ & 0.33 & 0.65 & 1.00 & 1.00 & 1.00 & 1.00 & 1.73 & 3.87 & 5.92 & 1.73 & 2.24 & 2.65 & 0.20 & 0.33 & 1.00 & 0.24 \\
\hline $4 c$ & 0.13 & 0.17 & 0.26 & 0.17 & 0.26 & 0.58 & 1.00 & 1.00 & 1.00 & 0.45 & 0.58 & 1.00 & 0.17 & 0.26 & 0.58 & 0.00 \\
\hline $4 d$ & 0.14 & 0.20 & 0.33 & 0.38 & 0.45 & 0.58 & 1.00 & 1.73 & 2.24 & 1.00 & 1.00 & 1.00 & 0.17 & 0.26 & 0.58 & 0.03 \\
\hline $4 e$ & 0.33 & 0.65 & 1.00 & 1.00 & 3.00 & 5.00 & 1.73 & 3.87 & 5.92 & 1.73 & 3.87 & 5.92 & 1.00 & 1.00 & 1.00 & 0.34 \\
\hline
\end{tabular}

both newly calculated subcriteria weights and original weights of the EFQM model to evaluate the levels of institutionalization of six public institutions. Ranking results are compared for both different subcriteria weights. Institutions are scored in the range of 0-100 for each criterion by experts. In Table 11, these scores and their maximum and minimum values are presented. For each institution, mean of group benefit, maximum regret, and index value are calculated. The alternatives are ranked in Table 12 according to the proposed approach and EFQM criteria weights. By examining Condition 1 (acceptable advantage) and Condition 2 (acceptable stability in decision making) in the VIKOR method, it is determined that the institutions F, A, and $\mathrm{B}$ are similar according to Condition 1. Institutions $A$ and $B$ are alternatives to institution $F$ in the ranking.

\section{Validation of the proposed approach}

Statistical analysis of criteria weights of EFQM model and the criteria weights obtained as a result of implementation has been conducted with a paired sample t-Test in SPSS Software. The paired sample tTest includes dependent tests between two dependent groups. Dependent groups are related to each other. The criteria weights obtained from the implementation result and the criteria weights of the EFQM model and the results of the evaluation of the six institutions are analyzed by paired sample t-Test. As a result of the analysis, there are no statistically significant differences between these two groups. The H0 hypothesis is: "there is no statistically significant difference between the results of the institutions evaluated by the criteria weights of the EFQM model and the criteria weights 


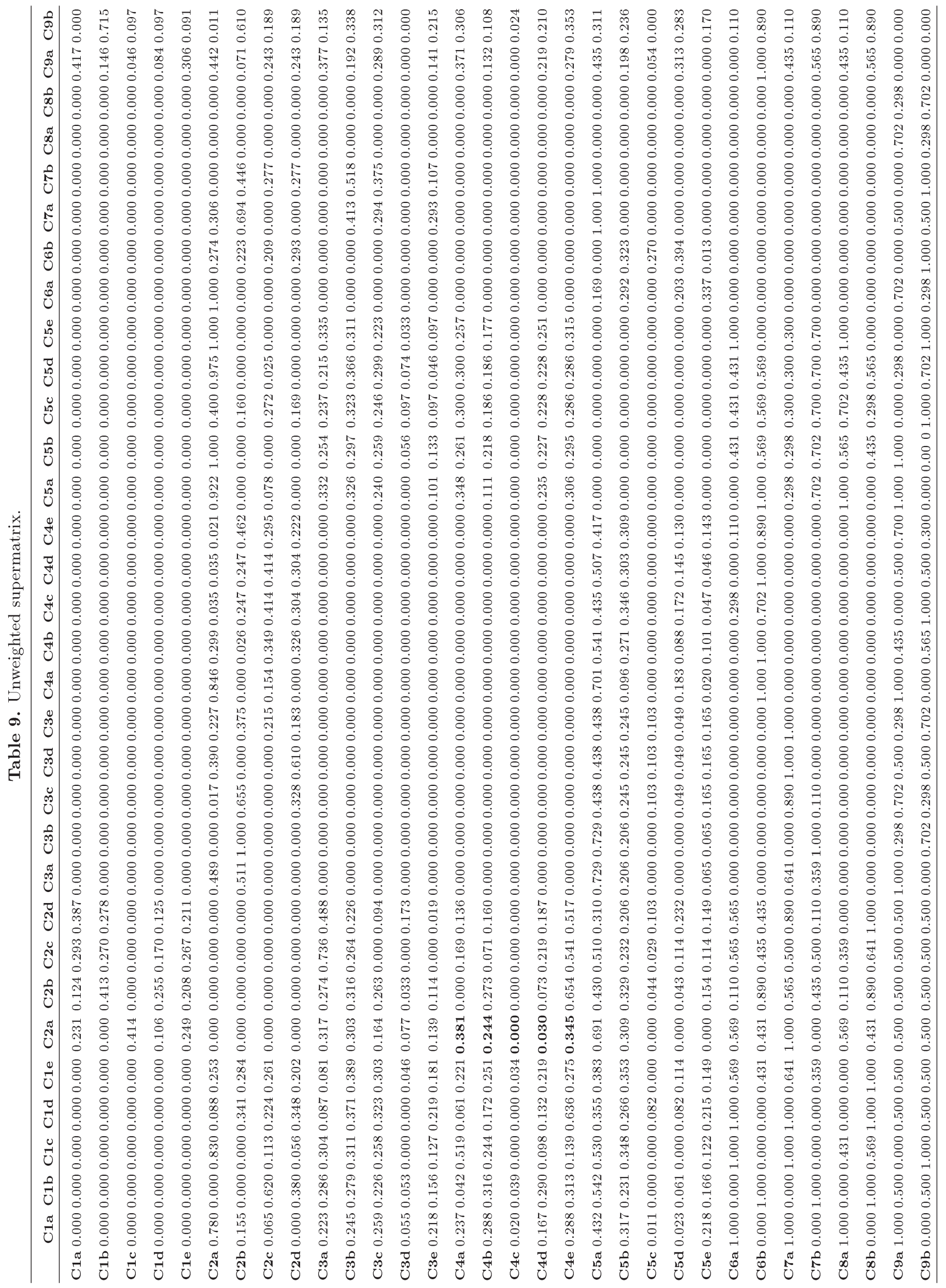




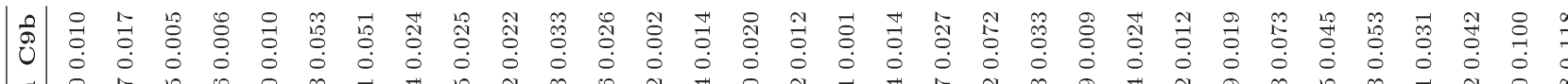

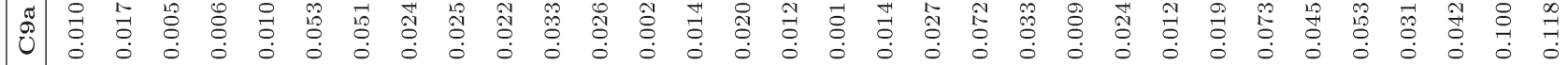

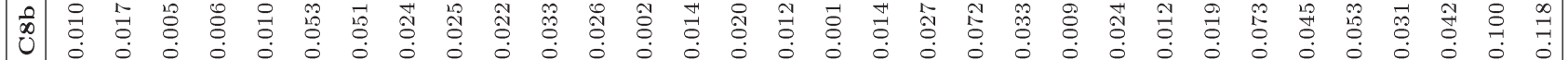

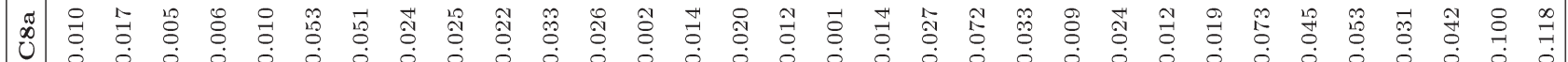

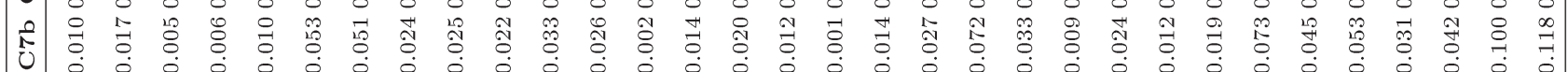
留 然 童

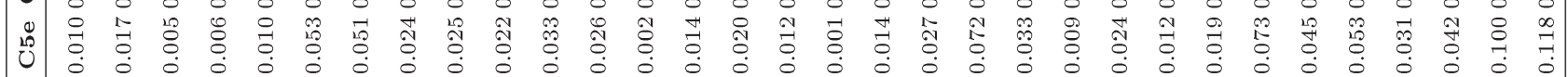

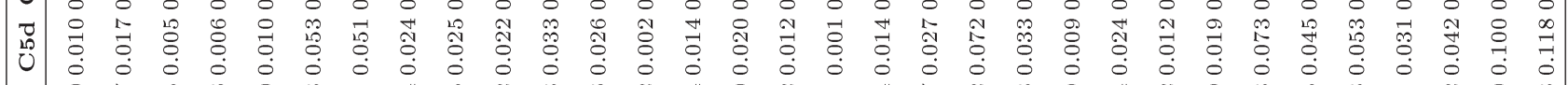

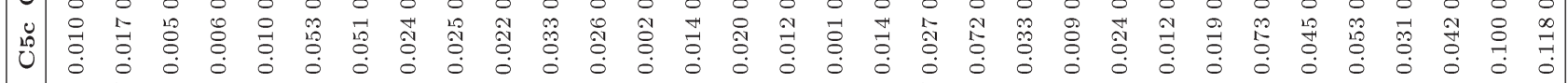

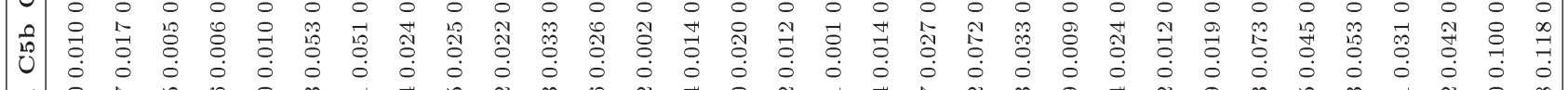

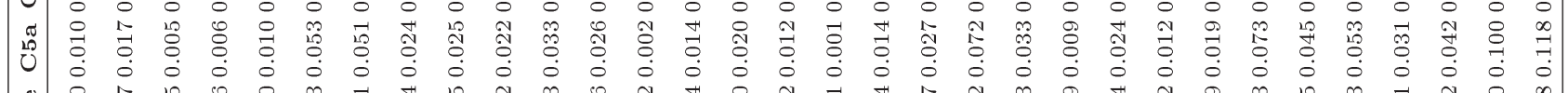

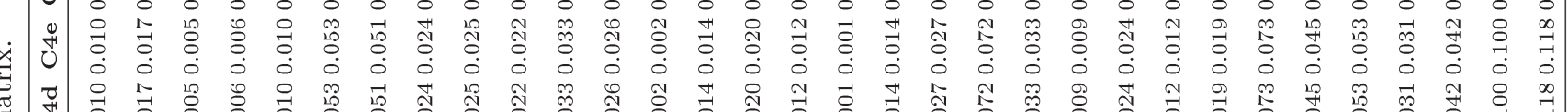
氙

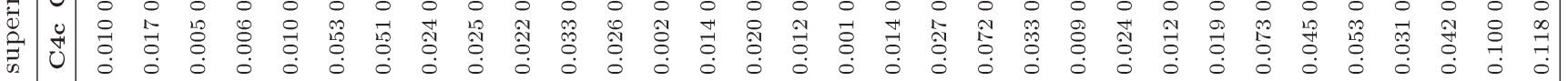

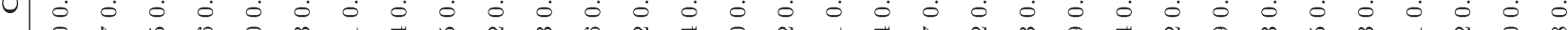

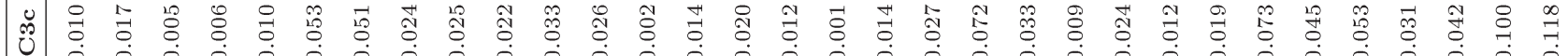
䓪

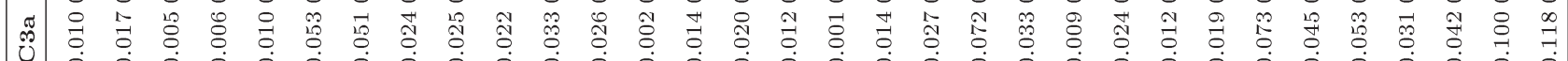

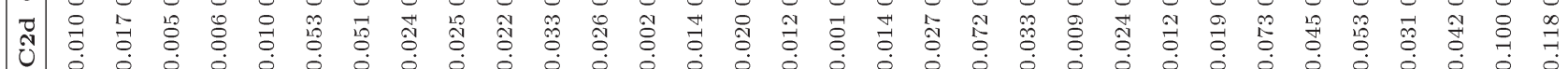

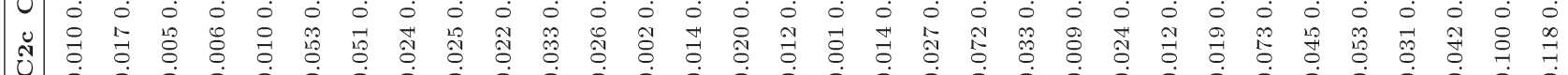

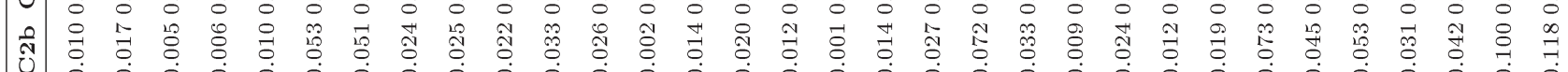

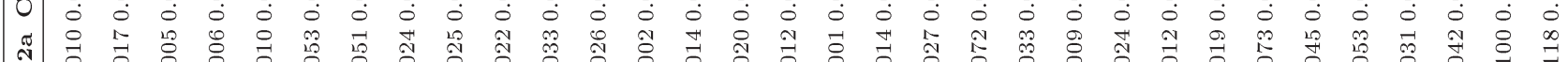

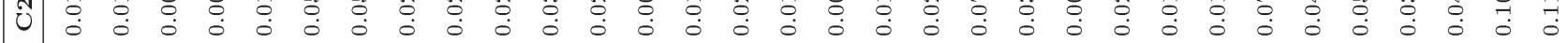

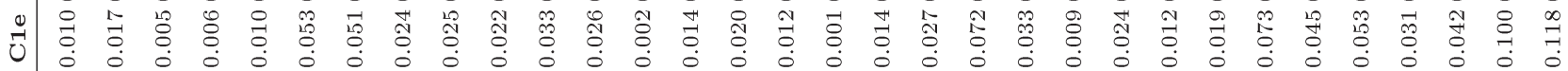
च

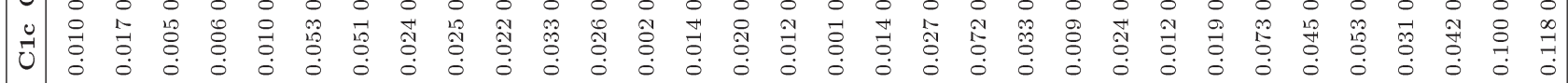

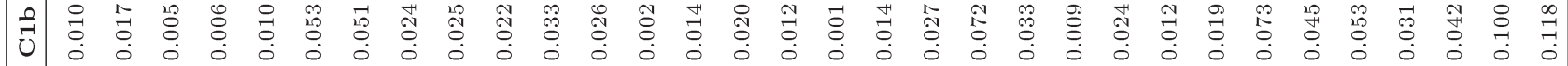

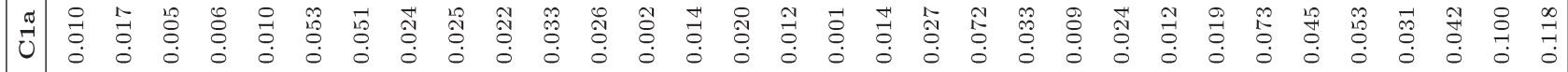

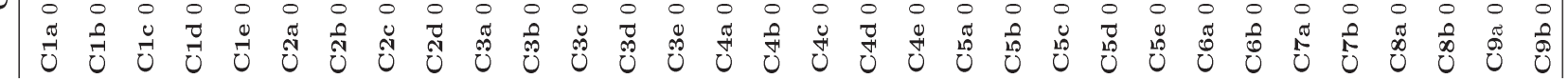


Table 11. Evaluation scores of enterprises according to sub-criteria.

\begin{tabular}{lcccccccc}
\hline & $\mathbf{A}$ & $\mathbf{B}$ & $\mathbf{C}$ & $\mathbf{D}$ & $\mathbf{E}$ & $\mathbf{F}$ & $\boldsymbol{f}_{j}^{*}$ & $\boldsymbol{f}_{j}^{-}$ \\
\hline $\mathbf{C 1 a}$ & 60 & 75 & 50 & 45 & 60 & 65 & 75 & 45 \\
$\mathbf{C 1 b}$ & 65 & 75 & 55 & 40 & 55 & 65 & 75 & 40 \\
$\mathbf{C 1 c}$ & 65 & 65 & 50 & 35 & 60 & 68 & 68 & 35 \\
$\mathbf{C 1 d}$ & 65 & 65 & 40 & 30 & 60 & 54 & 65 & 30 \\
$\mathbf{C 1 e}$ & 65 & 65 & 40 & 30 & 55 & 65 & 65 & 30 \\
$\mathbf{C 2 a}$ & 60 & 65 & 55 & 35 & 60 & 69 & 69 & 35 \\
$\mathbf{C 2 b}$ & 65 & 65 & 55 & 30 & 50 & 61 & 65 & 30 \\
$\mathbf{C 2 c}$ & 65 & 65 & 55 & 40 & 55 & 66 & 66 & 40 \\
$\mathbf{C 2 d}$ & 60 & 65 & 55 & 45 & 60 & 56 & 65 & 45 \\
$\mathbf{C 3 a}$ & 60 & 65 & 50 & 35 & 60 & 60 & 65 & 35 \\
$\mathbf{C 3 b}$ & 55 & 65 & 45 & 30 & 55 & 53 & 65 & 30 \\
$\mathbf{C 3 c}$ & 60 & 55 & 55 & 35 & 60 & 60 & 60 & 35 \\
$\mathbf{C 3 d}$ & 60 & 55 & 55 & 30 & 55 & 66 & 66 & 30 \\
$\mathbf{C 3 e}$ & 65 & 65 & 50 & 20 & 55 & 66 & 66 & 20 \\
$\mathbf{C 4 a}$ & 70 & 65 & 50 & 30 & 60 & 73 & 73 & 30 \\
$\mathbf{C 4 b}$ & 70 & 55 & 50 & 35 & 55 & 60 & 70 & 35 \\
$\mathbf{C 4 c}$ & 65 & 55 & 50 & 35 & 55 & 56 & 65 & 35 \\
$\mathbf{C 4 d}$ & 60 & 65 & 45 & 35 & 55 & 71 & 71 & 35 \\
$\mathbf{C 4 e}$ & 65 & 65 & 40 & 35 & 55 & 66 & 66 & 35 \\
$\mathbf{C 5 a}$ & 70 & 65 & 50 & 40 & 60 & 58 & 70 & 40 \\
$\mathbf{C 5 b}$ & 65 & 65 & 60 & 40 & 55 & 68 & 68 & 40 \\
$\mathbf{C 5 c}$ & 60 & 65 & 40 & 35 & 55 & 66 & 66 & 35 \\
$\mathbf{C 5 d}$ & 70 & 55 & 55 & 40 & 55 & 60 & 70 & 40 \\
$\mathbf{C 5 e}$ & 70 & 65 & 50 & 40 & 55 & 60 & 70 & 40 \\
$\mathbf{C 6 a}$ & 60 & 65 & 45 & 50 & 65 & 71 & 71 & 45 \\
$\mathbf{C 6 b}$ & 60 & 65 & 45 & 45 & 65 & 59 & 65 & 45 \\
$\mathbf{C 7 a}$ & 60 & 55 & 45 & 50 & 65 & 68 & 68 & 45 \\
$\mathbf{C 7 b}$ & 55 & 45 & 45 & 55 & 65 & 60 & 65 & 45 \\
$\mathbf{C 8 a}$ & 45 & 55 & 45 & 50 & 60 & 56 & 60 & 45 \\
$\mathbf{C 8 b}$ & 50 & 55 & 40 & 55 & 60 & 56 & 60 & 40 \\
$\mathbf{C 9 a}$ & 60 & 65 & 45 & 50 & 55 & 69 & 69 & 45 \\
$\mathbf{C 9 b}$ & 65 & 65 & 45 & 50 & 70 & 68 & 70 & 45 \\
\hline & & & & & & & &
\end{tabular}

obtained as a result of the implementation". The H1 hypothesis is: "there is a statistically significant difference between the results of the institutions evaluated by the criteria weights of the EFQM model and the criteria weights obtained as a result of the implementation". According to both results at a $95 \%$ confidence level and a $99 \%$ confidence level, the test statistic value and the test significance are 1.24667 and
0.601 , respectively. The H0 hypothesis is accepted because the significance value is greater than 0.001 for both confidence levels. It is concluded that there are no statistically significant differences between the results of the evaluation of the six institutions using the criteria weights of the EFQM model and the criteria weights obtained from the proposed implementation approach.

\section{Results and discussions}

In this study, the main criteria weights of the existing EFQM are analytically calculated via integrated MCDM methods. When the calculated weights are taken into consideration, weights of some criteria have decreased, namely leadership (from $10 \%$ to $5 \%$ ), partnership and resources (from $10 \%$ to $7 \%$ ), customer (from $15 \%$ to $9 \%$ ), and society (from $10 \%$ to $7 \%)$. On the other hand, weights of some criteria have increased, namely strategy (from $10 \%$ to $15 \%$ ), processes, products and services (from 10\% to 15\%), and business results (from $15 \%$ to $22 \%$ ). Furthermore, the weights of people $(10 \%)$ and people results $(10 \%)$ criteria have not changed. Business Results, including key performance outcomes and indicators, have become the most essential criteria based on the proposed method. Consequently, the statistical validation process confirmed that determining criteria weights by fuzzy integrated MCDM methods showed no significant difference between the total scores of 6 public institutions calculated by the EFQM and the proposed model. Thus, the proposed approach could be used for evaluating the institutions during a real assessment process as an alternative to the original EFQM.

The excellence levels of institutions A, B, C, D, $\mathrm{E}$, and $\mathrm{F}$ have been calculated according to EFQM's criterion weights of the proposed approach in Table 13. When enterprises' excellence level scores are compared, institutions A, B, E, and F deserve to receive the excellence award by getting 501 points and above. Institu-

Table 12. Comparison of the ranking alternatives according to the proposed approach and EFQM.

\begin{tabular}{|c|c|c|c|c|c|c|}
\hline & $S_{i}$ & Ranking & $\boldsymbol{R}_{i}$ & Ranking & $Q_{i}$ & Ranking \\
\hline \multirow{6}{*}{ 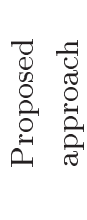 } & 0.147 & $\mathrm{~F}$ & 0.029 & $\mathrm{~F}$ & 0 & $\mathrm{~F}$ \\
\hline & 0.200 & B & 0.053 & A & 0.110 & A \\
\hline & 0.238 & A & 0.037 & B & 0.173 & B \\
\hline & 0.244 & $\mathrm{E}$ & 0.058 & $\mathrm{E}$ & 0.232 & $\mathrm{E}$ \\
\hline & 0.746 & $\mathrm{C}$ & 0.118 & D & 0.867 & D \\
\hline & 0.874 & $\mathrm{D}$ & 0.094 & $\mathrm{C}$ & 0.912 & $\mathrm{C}$ \\
\hline \multirow{6}{*}{ 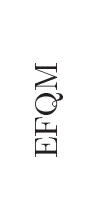 } & 0.123 & $\mathrm{~F}$ & 0.0133 & $\mathrm{~F}$ & 0 & $\mathrm{~F}$ \\
\hline & 0.209 & B & 0.0424 & B & 0.204 & B \\
\hline & 0.249 & $\mathrm{E}$ & 0.0438 & $\mathrm{E}$ & 0.238 & $\mathrm{E}$ \\
\hline & 0.272 & A & 0.0500 & A & 0.285 & A \\
\hline & 0.769 & C & 0.1125 & D & 0.891 & D \\
\hline & 0.865 & D & 0.0909 & $\mathrm{C}$ & 0.936 & $\mathrm{C}$ \\
\hline
\end{tabular}


Table 13. Organizational excellence levels according to the EFQM criteria and the proposed approach.

\begin{tabular}{|c|c|c|c|c|c|c|c|}
\hline & & $\mathbf{A}$ & B & $\mathrm{C}$ & D & $\mathbf{E}$ & $\mathbf{F}$ \\
\hline \multirow{32}{*}{ 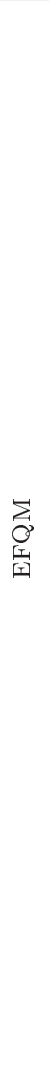 } & C1a & 12.00 & 15.00 & 10.00 & 9.00 & 12.00 & 13.00 \\
\hline & C1b & 13.00 & 15.00 & 11.00 & 8.00 & 11.00 & 13.00 \\
\hline & $\mathrm{C} 1 \mathrm{c}$ & 13.00 & 13.00 & 10.00 & 7.00 & 12.00 & 13.60 \\
\hline & C1d & 13.00 & 13.00 & 8.00 & 6.00 & 12.00 & 10.80 \\
\hline & C1e & 13.00 & 13.00 & 8.00 & 6.00 & 11.00 & 13.00 \\
\hline & $\mathrm{C2a}$ & 15.00 & 16.25 & 13.75 & 8.75 & 15.00 & 17.25 \\
\hline & $\mathrm{C} 2 \mathrm{~b}$ & 16.25 & 16.25 & 13.75 & 7.50 & 12.50 & 15.25 \\
\hline & $\mathrm{C} 2 \mathrm{c}$ & 16.25 & 16.25 & 13.75 & 10.00 & 13.75 & 16.50 \\
\hline & C2d & 15.00 & 16.25 & 13.75 & 11.25 & 15.00 & 14.00 \\
\hline & C3a & 12.00 & 13.00 & 10.00 & 7.00 & 12.00 & 12.00 \\
\hline & $\mathrm{C} 3 \mathrm{~b}$ & 11.00 & 13.00 & 9.00 & 6.00 & 11.00 & 10.60 \\
\hline & C3c & 12.00 & 11.00 & 11.00 & 7.00 & 12.00 & 12.00 \\
\hline & C3d & 12.00 & 11.00 & 11.00 & 6.00 & 11.00 & 13.20 \\
\hline & $\mathrm{C3e}$ & 13.00 & 13.00 & 10.00 & 4.00 & 11.00 & 13.20 \\
\hline & $\mathrm{C} 4 \mathrm{a}$ & 14.00 & 13.00 & 10.00 & 6.00 & 12.00 & 14.60 \\
\hline & $\mathrm{C} 4 \mathrm{~b}$ & 14.00 & 11.00 & 10.00 & 7.00 & 11.00 & 12.00 \\
\hline & $\mathrm{C} 4 \mathrm{c}$ & 13.00 & 11.00 & 10.00 & 7.00 & 11.00 & 11.20 \\
\hline & $\mathrm{C} 4 \mathrm{~d}$ & 12.00 & 13.00 & 9.00 & 7.00 & 11.00 & 14.20 \\
\hline & $\mathrm{C4e}$ & 13.00 & 13.00 & 8.00 & 7.00 & 11.00 & 13.20 \\
\hline & C5a & 14.00 & 13.00 & 10.00 & 8.00 & 12.00 & 11.60 \\
\hline & C5b & 13.00 & 13.00 & 12.00 & 8.00 & 11.00 & 13.60 \\
\hline & C5c & 12.00 & 13.00 & 8.00 & 7.00 & 11.00 & 13.20 \\
\hline & C5d & 14.00 & 11.00 & 11.00 & 8.00 & 11.00 & 12.00 \\
\hline & C5e & 14.00 & 13.00 & 10.00 & 8.00 & 11.00 & 12.00 \\
\hline & $\mathrm{C} 6 \mathrm{a}$ & 67.50 & 73.13 & 50.63 & 56.25 & 73.125 & 79.875 \\
\hline & $\mathrm{C} 6 \mathrm{~b}$ & 22.50 & 24.38 & 16.88 & 16.88 & 24.375 & 22.125 \\
\hline & $\mathrm{C} 7 \mathrm{a}$ & 45.00 & 41.25 & 33.75 & 37.50 & 48.75 & 51.00 \\
\hline & $\mathrm{C} 7 \mathrm{~b}$ & 13.75 & 11.25 & 11.25 & 13.75 & 16.25 & 15.00 \\
\hline & $\mathrm{C} 8 \mathrm{a}$ & 22.50 & 27.50 & 22.50 & 25.00 & 30.00 & 28.00 \\
\hline & $\mathrm{C8b}$ & 25.00 & 27.50 & 20.00 & 27.50 & 30.00 & 28.00 \\
\hline & C9a & 45.00 & 48.75 & 33.75 & 37.50 & 41.25 & 51.75 \\
\hline & $\mathrm{C} 9 \mathrm{~b}$ & 48.75 & 48.75 & 33.75 & 37.50 & 52.50 & 51.00 \\
\hline \multirow{34}{*}{ 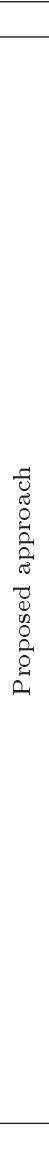 } & Total & 609.50 & 621.50 & 473.50 & 428.38 & 599.50 & 641.75 \\
\hline & C1a & 5.76 & 7.20 & 4.80 & 4.32 & 5.76 & 6.24 \\
\hline & C1b & 10.80 & 12.47 & 9.14 & 6.65 & 9.14 & 10.80 \\
\hline & $\mathrm{C} 1 \mathrm{c}$ & 3.08 & 3.08 & 2.37 & 1.66 & 2.84 & 3.22 \\
\hline & C1d & 3.69 & 3.69 & 2.27 & 1.70 & 3.41 & 3.07 \\
\hline & C1e & 6.23 & 6.23 & 3.83 & 2.88 & 5.27 & 6.23 \\
\hline & $\mathrm{C2a}$ & 31.74 & 34.38 & 29.09 & 18.51 & 31.74 & 36.50 \\
\hline & $\mathrm{C} 2 \mathrm{~b}$ & 32.95 & 32.95 & 27.88 & 15.21 & 25.35 & 30.92 \\
\hline & $\mathrm{C} 2 \mathrm{c}$ & 15.46 & 15.46 & 13.08 & 9.52 & 13.08 & 15.70 \\
\hline & C 2d & 14.91 & 16.15 & 13.67 & 11.18 & 14.91 & 13.92 \\
\hline & C3a & 13.00 & 14.08 & 10.83 & 7.58 & 13.00 & 13.00 \\
\hline & $\mathrm{C} 3 \mathrm{~b}$ & 18.20 & 21.51 & 14.89 & 9.93 & 18.20 & 17.54 \\
\hline & $\mathrm{C} 3 \mathrm{c}$ & 15.86 & 14.54 & 14.54 & 9.25 & 15.86 & 15.86 \\
\hline & C3d & 1.31 & 1.20 & 1.20 & 0.65 & 1.20 & 1.44 \\
\hline & C3e & 9.41 & 9.41 & 7.24 & 2.90 & 7.96 & 9.55 \\
\hline & $\mathrm{C4a}$ & 14.16 & 13.15 & 10.11 & 6.07 & 12.14 & 14.77 \\
\hline & $\mathrm{C} 4 \mathrm{~b}$ & 8.53 & 6.70 & 6.09 & 4.26 & 6.70 & 7.31 \\
\hline & $\mathrm{C} 4 \mathrm{c}$ & 0.33 & 0.28 & 0.25 & 0.18 & 0.28 & 0.28 \\
\hline & C4d & 8.35 & 9.04 & 6.26 & 4.87 & 7.65 & 9.88 \\
\hline & $\mathrm{C4e}$ & 17.27 & 17.27 & 10.63 & 9.30 & 14.62 & 17.54 \\
\hline & C5a & 50.73 & 47.10 & 36.23 & 28.99 & 43.48 & 42.03 \\
\hline & C5b & 21.23 & 21.23 & 19.60 & 13.07 & 17.97 & 22.21 \\
\hline & C5c & 5.45 & 5.90 & 3.63 & 3.18 & 5.00 & 5.99 \\
\hline & C5d & 16.57 & 13.02 & 13.02 & 9.47 & 13.02 & 14.20 \\
\hline & C5e & 8.37 & 7.77 & 5.98 & 4.78 & 6.58 & 7.18 \\
\hline & $\mathrm{C} 6 \mathrm{a}$ & 11.51 & 12.47 & 8.63 & 9.59 & 12.47 & 13.62 \\
\hline & $\mathrm{C} 6 \mathrm{~b}$ & 43.54 & 47.16 & 32.65 & 32.65 & 47.16 & 42.81 \\
\hline & $\mathrm{C} 7 \mathrm{a}$ & 26.80 & 24.57 & 20.10 & 22.34 & 29.04 & 30.38 \\
\hline & $\mathrm{C} 7 \mathrm{~b}$ & 29.25 & 23.93 & 23.93 & 29.25 & 34.57 & 31.91 \\
\hline & $\mathrm{C} 8 \mathrm{a}$ & 14.00 & 17.11 & 14.00 & 15.55 & 18.66 & 17.42 \\
\hline & $\mathrm{C} 8 \mathrm{~b}$ & 21.15 & 23.26 & 16.92 & 23.26 & 25.38 & 23.68 \\
\hline & $\mathrm{C} 9 \mathrm{a}$ & 59.94 & 64.93 & 44.95 & 49.95 & 54.94 & 68.93 \\
\hline & $\mathrm{C} 9 \mathrm{~b}$ & 76.42 & 76.42 & 52.91 & 58.79 & 82.30 & 79.95 \\
\hline & Total & 615.99 & 623.68 & 480.74 & 427.47 & 599.66 & 634.07 \\
\hline
\end{tabular}


tions C and D are entitled to receive the 4-Star Competency Certificate by scoring 401 points and above.

\section{Conclusion}

The literature clearly demonstrates that institutionalization is vital both in terms of achieving success and providing sustainability. The most important feature that distinguishes enterprises is their institutionalization level. A case study of six public organizations was investigated using the criteria of the EFQM excellence model. The fuzzy DEMATEL method was used to determine the interactions amongst the main criteria in the developed approach. Thus, relations amongst the criteria were determined via expert opinions. The criteria relations obtained by the Fuzzy DEMATEL method provided input to the Fuzzy ANP method. The most important criteria and weights for institutions to be considered institutionalized were determined. The business results criterion was thus considered the most important factor in institutionalization. The institutionalization levels of the 6 public institutions were ranked, and the levels of excellence were evaluated by means of VIKOR method. According to the developed and EFQM model, it was determined that institution $\mathrm{F}$ was the best institution. Institutions $\mathrm{A}$ and $\mathrm{B}$ may be considered alternatives to Institution $\mathrm{F}$. The proposed approach was compared with the weights of the EFQM model, showing that there were no statistical differences between the EFQM weights and the criteria weights obtained as a result of implementation. Consequently, thanks to the proposed model, six public institutions were assessed and, then, the results were validated via comparison with the EFQM model.

\section{References}

1. Aydemir, O.T., Alpkan, L., Kitapçı, H., et al. "Özeǧerleme modellerinin denge skor kartğyla entegre edilmesi: bir özdeğerleme modeli önerisi", Dumlupınar Üniversitesi Sosyal Bilimler Dergisi, 25(1), pp. 205220 (2015).

2. Steed, C., Maslow, D., and Mazaletskaya, A. "The EFQM excellence model for deploying quality management: A British-Russian journey", Higher Education Eur, 30, pp. 307-319 (2005).

3. Yazici, S. "Mükemmellikte yeni arayışlar: EFQM mükemmellik modeli ve örgütsel öğrenme", Ön Kalite Derneği, 39, pp. 32-38 (2000).

4. Yaghoubi, N.M., Bandeii, M., and Moloudi, J. "An empirical study of the EFQM excellence model in Iran", International Journal of Business Management, 6(5), p. 260 (2011).

5. European Foundation for Quality Management (EFQM), EFQM Model for Business Excellence, Brussels: EFQM (2012).
6. Liu, Y.-H. and Ko, P.-F. "A modified EFQM Excellence Model for effective evaluation in the hotel industry", Total Quality Management Business Excellence, 29(13), pp. 1-14 (2017).

7. Ziaei, A.E., Alirezaee, H., Riyahi, A., et al. "Assess causal relationships of EFQM model criteria using fuzzy dematel", Int Bus Manag, 10(11), pp. 2185-2189 (2016).

8. Taji, M., Siadat, A., and Hoveida, R. "Identification and ranking of key factors influencing organizational agility implementation on total quality management", Int Bus Manag, 10(15), pp. 2814-2822 (2016).

9. Najafi, A. and Naji, E. "Implementing the EFQM model in the calcimin company using the fuzzy hybrid electre approach", Indian Journal Sci Technol, 9(44), pp. 1-7 (2016).

10. Saryazdi, M.D., Eslami, H., Shakerian, H., et al. "Utilizing fuzzy expert system in organizations' performance assessment", IIOAB J, 7, pp. 410-417 (2016).

11. Hosseini, J.E., Dehghani, M.S., and Mostafaeipour, A. "Implementing fuzzy logic and AHP into the EFQM model for performance improvement: A case study", Applied Soft Computer, 36, pp. 165-176 (2015).

12. Sajedi, M.A. "An improved TOPSIS/EFQM methodology for evaluating the performance of organizations", Life Sci. J., 10(1), pp. 4315-4322 (2013).

13. Aydin, S., Kahraman, C., and Kaya, I. "A new fuzzy multicriteria decision making approach: An application for European quality award assessment", Knowledge Based Systems, 32, pp. 37-46 (2012).

14. Daniel, J., Yusuff, R.M., and Jassbi, J. "Assessment system based on fuzzy scoring in European foundation for quality management (EFQM): Business excellence model", 5(15), pp. 6209-6220 (2011).

15. Dodangeh, J., Yusuff, R.M., Ismail, N., et al. "Designing fuzzy multi criteria decision making model for best selection of areas for improvement in European foundation for quality management (EFQM) model", Afr J. Bus. Manag., 5(12), p. 5010 (2011).

16. Paghaleh, M.J. "Performance measurement by EFQM excellence model with fuzzy approach", Aust. J. Basic Appl. Sci., 5(10), pp. 1020-1024 (2001).

17. Kahveci, T.C. "The institutionalization and the enterprise modeling in the manufacturing firms", Dissertation, Sakarya University (2007).

18. Dinç, E. "Muhasebe bilgi sistemi ve kurumsallaşma düzeyi arasındaki ilişkiye yönelik bir araştırma", Sosyal ve Ekonomik Araştırmalar Dergisi, 27(1), pp. 21-50 (2014).

19. Alpay, G., Bodur, M., Yılmaz, C., et al. "Performance implications of institutionalization process in familyowned businesses: evidence from an emerging economy", Journal World Business, 43(4), pp. 435-448 (2008). 
20. Uygun, Ö., Kahveci, T.C., Taşkın, H., et al. "Readiness assessment model for institutionalization of SMEs using fuzzy hybrid MCDM techniques", Computer Industrial Engineering, 88(1), pp. 217-228 (2015).

21. Çömlek, O. "Özdeğerlendirme ve verimlilik analizi yoluyla performans değerlendirmeye yönelik bir model önerisi", Dissertation, Gebze Yüksek Teknoloji Enstitüsü İşletme Anabilim Dalı (2009).

22. Chaghooshi, A.J., Rahmani, M., and Mohammad, K.Z. "Formulation and prioritization of strategies in tile and ceramic industry: a case study", N. Y. Sci. J., 5(6), pp. 79-87 (2012).

23. Wu, H.Y., Lin, Y.K., and Chang, C.H. "Performance evaluation of extension education centers in universities based on the balanced scorecard", Evaluation Program Plan, 34(1), pp. 37-50 (2011).

24. Liou, J.H. and Chuang, Y.T. "Developing a hybrid multi-criteria model for selection of outsourcing providers", Expert Syst. Appl., 37(5), pp. 3755-3761 (2010).

25. Lin, C.J., and Wu, W.W. "A fuzzy extension of the dematel method for group decision making", Eur. J. Oper. Res., 156, pp. 445-455 (2004).

26. Lin, C.J. and Wu, W.W. "A causal analytical method for group decision-making under fuzzy environment", Int. J. Qual. Reliab. Manag., 34(1), pp. 205-213 (2008).

27. Saaty, T.L. "The analytic network process. In Decision making with the analytic network process", Springer, Boston, MA. pp. 1-26 (2006).

28. Chang, D.Y. "Applications of the extent analysis method on fuzzy AHP", Eur. J. Oper. Res., 95(3), pp. 649-655 (1996).

29. Opricovic, S. "Multicriteria optimization of civil engineering systems", Faculty of Civil Engineering, Belgrade, 2(1), pp. 5-21 (1998).

30. Opricovic, S. and Tzeng, G.H. "Multicriteria planning of post-earthquake sustainable reconstruction", Computer Aided Civ. Infrastruct. Eng., 17(1), pp. 211-220 (2002).

31. Poyraz, B. "The effects of self assessment study which is made on people criteria of European excellence model on human resources activities - a case study", Dissertation, Dokuz Eylül University (2008).

\section{Biographies}

Özer Uygun was born in Sakarya, Turkey in 1976. He received his BS degree in 1999, his MS degree in 2002 and $\mathrm{PhD}$ degree in 2008 in Industrial Engineering from Sakarya University, Turkey. He started his academic position at Marmara University and worked as a Lecturer between 2000 and 2003. Then, he worked as a Research Assistant at Sakarya University between 2003 and 2008 and, now, works as an Associate Professor at this university. He was a researcher in EU FP6 Network of Excellence (I*PROMS: 2004-2009) and FP6 STREP Project (IWARD: 2007-2009). He has successfully completed the EFQM Assessor Training in Brussels in 2015.

Selin Yalçın was born in Istanbul, 1992. She completed both her primary and high school educations in Istanbul. She graduated from Industrial Engineering at Beykent University 2014. During undergraduate studies, she started at the Department of Mechanical Engineering as Double Major between 2011-2014. She was awarded the scholarship due to her academic accomplishment as the 1st GPA among her classmates in 2013. Between 2015-2017, she received her MD in the field of Industrial Engineering, from Sakarya University. Afterwards, in 2017, she started his Doctor of Philosophy at the Department of Industrial Engineering at Yıldız Teknik University. She has been working as a Research Assistant at Beykent University, Department of Industrial Engineering, since 2017.

Alper Kiraz is an Assistant Professor at the Industrial Engineering Department at Sakarya University where he has been a faculty member since 2007. He has been an assessor of EFQM (European Foundation for Quality Management) excellence model since 2015. Dr. Kiraz completed his PhD at Sakarya University. His research interests are fuzzy logic, artificial neural networks, multi-criteria decision-making methods, quality management, optimization, and virtual laboratories. He joined several conferences on his research area and has about 30 conference papers, 6 articles in indexed journals, 3 book chapters, 3 national research projects, etc. He has served as a referee in the Journal of Computer Engineering \& Information Technology and Sakarya University Journal of Science.

Enes Furkan Erkan graduated from Sakarya University in 2015. He has been studying at Sakarya University, Industrial Engineering Department, as a Research Assistant since 2015. His topics of interest include fuzzy logic, fuzzy multi-criteria decision making methods, institutionalization, and management systems. He received his MD at Sakarya University in 2017. 